Print ISSN: 2288-4637 / Online ISSN 2288-4645

doi:10.13106/jafeb.2019.vol6.no3.259

\title{
The Effect of Emotional Image on Customer Attitude
}

\author{
Hyeyoon PARK ${ }^{1}$, Soyeon PARK ${ }^{2}$
}

Received: March 26, 2019 Revised: April 18, 2019 Accepted: July 3, 2019

\begin{abstract}
This study examines the color image of uniform of airline cabin crew according to the demographic characteristics of the customer and demonstrates how it affects the cognitive image of airlines. Adjective adjectives were derived for uniform color images of all eight airlines in Korea and analyzed the image of airline brand color. Based on the analysis of color images, the difference in perception according to the demographic characteristics of passengers was analyzed. When the colors of airline uniforms are mainly blue, sky blue, white and ivory, they have a lot of trust, neat and elegant images. Uniforms with primary colors such as red, orange and green beans are found to have a lot of cheerful, developmental and enterprising images. In addition, the empirical analysis of the impact of the customer's cognitive perception and favoritism on the uniform color image of the airline crew showed that the more positive the airline's positive perception of the uniform color image, the more positive the cognitive image is. In other words, the empirical analysis revealed that the airline's uniform color image, its cognitive image of the airline, and its popularity have significant positive relationships.
\end{abstract}

Keywords: Emotional Image, Customer Attitude, Airline Uniform, Demographic Characteristic.

JEL Classification Code: L21, L26, L60, M12

\section{Introduction}

As a result of the globalization of the air transportation market and the deregulation of airlines, the number of airlines is increasing. Customers are choosing a wide range of airlines, and airlines are working to create their own appeal to attract customers. This is for the profit and growth of airlines. It also shows the importance of airline image management in airline management. Airline management is selling intangible services unlike ordinary companies in production and sales. This is linked to the image created by human services. Air transportation is a business that provides air transportation to a specific destination with the same product called an airplane. However, as competition between air carriers deepens, various marketing and pricing policies make it difficult to survive in competition.

1 First Author and Corresponding Author. Professor, Department of Aviation Tourism, Hanseo University, Korea.

Email : hypark@hanseo.ac.kr

2 Professor, Department of Aviation Tourism, Hanseo University, Korea. Email : sypark@hanseo.ac.kr

(c) Copyright: Korean Distribution Science Association (KODISA)

This is an Open Access article distributed under the terms of the Creative Commons Attribution NonCommercial License (https://creativecommons.org/licenses/by-nc/4.0/) which permits unrestricted noncommercial use, distribution, and reproduction in any medium, provided the original work is properly cited.
The services provided by airline cabin crews are most closely related to customers. In the aircraft cabin, the crew face the customers directly and provide services. Thus, the image of the airline cabin crew can be a symbolic image representing the airline.

In the aviation industry, which provides intangible products such as services that are not selling typified products to consumers, positive emotional image and loyalty to the corporation are the top priority companies' competitiveness. This plays a crucial role in distinguishing airline companies from other airline companies that have no significant difference between competitive airline companies, except for the convenience of schedule and price competitiveness, and plays an important role as an effective marketing tool.

As one of the core marketing strategies of many airlines, we are making efforts to improve the convenience of passengers by constructing differentiated brand image and developing more convenient cabin interior through whole brand renewal work(Kim, Ha, \& An, 2014). The services the airline provides for passengers more enjoyable and safe journeys are an important factor in determining the image of the airline. Among these processes, it is the crew who have the longest time to face the customer and perform various tasks, and their uniforms play an important role in directly 
connecting with the image of the airline. Airline uniforms are a very effective means of establishing and communicating the cultural identity of the country as well as the image of the company itself. Color is an emotional tool that is an important means of emotional image and affective image for passengers to the airline. It conveys the image with stronger persuasiveness than the form and appeals to the emotional rather than the opposite gender. It is responsible for the communication role. In addition, since color is a visual language that provides the most intelligent visual information among human senses, use of color is very important in the aviation industry that needs to build up brand image for the whole world (Park, 2016). The purpose of this study is to present the business and practical implications to Korean airlines by using the color images of airline uniforms to understand the emotional image, affective image and its impact on consumers' loyalty. Through this, airlines will move away from passive marketing and recognize the importance of using color images in positioning themselves as global competitors.

The purpose of this study is to examine the differences in the uniform color of airline crew according to the demographic characteristics of customers. Second, based on the theoretical studies of previous studies, we set up and measure research model designs and hypotheses about the effects of uniform color on emotional image and loyalty.

\section{Literature Review}

\subsection{Uniform Color Image}

An airline color image represents a defined color that represents an airline or commodity as a face that symbolizes or represents an airline. In other words, it represents the corporate identity in color. Aaker(1991) said "Human judgment about design and form is more mental and rational, but the response to color is emotional. In other words, form appeals to human reason, but color appeals to human emotion. It was so impressive that it was easy to remember. Color affects human physiological and psychological thinking and acts as an important element of visual communication that effectively performs information transfer function. Due to the characteristics of color, attention, awareness, and memory, customers are becoming more influenced by color changes and other emotional changes (Seo, Kim, \& Lee, 2018).

The symbolism of color is instantly reminiscent of a company when color stimulation is given, which leads to the interaction of color and company, resulting in natural and friendly potential for consumers, resulting in favorable and loyal entrepreneurship, and selection and purchasing effects. Being able to associate with a specific company or a specific color means that the company has a favorable position in consumer perception. Color is a competitive element that creates low cost and high profit by differentiating point that appeals to consumer sensitivity by raising brand value independently (Lee, 2017).

Colors applied consistently to logos and symbols such as corporate visual elements are used to communicate corporate philosophy and vision to consumers and establish differentiated corporate image. Such efficient use of color has a great influence on the rise of brand image and pursuit of profit (Sanjeev, Pranay, Chandan, \& Sai, 2015). Based on the above theoretical and empirical basis, this study aims to demonstrate the relationship between affective image and customer loyalty through the following hypothesis:

H1: The airline crew's perception of uniform color images will vary depending on demographic characteristics.

\subsection{Emotional Image}

The preference for a particular object or service enhances customer loyalty for continued use.

Strengthened loyalty keeps customers from escaping, keeps customers up to date, reduces the likelihood of customers switching to another product or service, and encourages others to recommend a product, service, or brand. Choi and Bae (1999) emphasized the importance of travel agency image in the study of relationship between travel agency color image and customer loyalty. Kim and Lee (2013) showed that festival color image unity influences city brand commitment and local loyalty, and that coincidence had a positive effect on local loyalty. Oh, Shim, and Shin (2002) reported that customer loyalty increases as the store color image increases in the effect of virtual store image on satisfaction, trust and loyalty in e-commerce. Ishaq (2012) found that the effect of store personality and functional store image on the store loyalty influences the functional loyalty, and that the higher the functional store image, the higher the store loyalty.

Kim and Rye (2009) argue that the color image of the convention center has a significant effect on customer loyalty in the influence of convention attendees' convention center image on satisfaction and loyalty. Ha (2010) studied the relationship between brand color image, affective image and brand loyalty, while previous studies focused on crosssectional study centering on a specific point in time, while studying the relationship between brand image, affective image and brand loyalty, The importance of brand image, affective image is crucial to build brand loyalty from a longterm perspective, and the study shows that the brand image 
is strengthened over time. Lee (2012) said that the perception of color image of Korean native food brand affects the attitude and loyalty, and the restaurant brand image affects customer loyalty. Back (2005) found that the brand color image of a luxury hotel had a positive (+) direct effect on image loyalty in perceived value and brand loyalty of perceived value and brand loyalty. Through previous studies, this study aims to clarify the importance of airline cabin crew's color image management in order to increase airline loyalty of airlines.

Based on the above theoretical and empirical basis, this study aims to demonstrate the relationship between affective image and customer loyalty through the following hypothesis:

H2: Affective image of Airline flight attendant uniform color will have a positive impact on customer loyalty.

\section{Research Method and Measurement}

\subsection{Research Model and Variables}

The purpose of this study is to clarify the difference of brand association according to the demographic characteristics of the crew uniform color image of the domestic airline and to clarify the relation between the emotion image and the loyalty of the color image of the airline crew uniform. In order to clarify the purpose of this research through empirical analysis, the following research model was established through academic research.

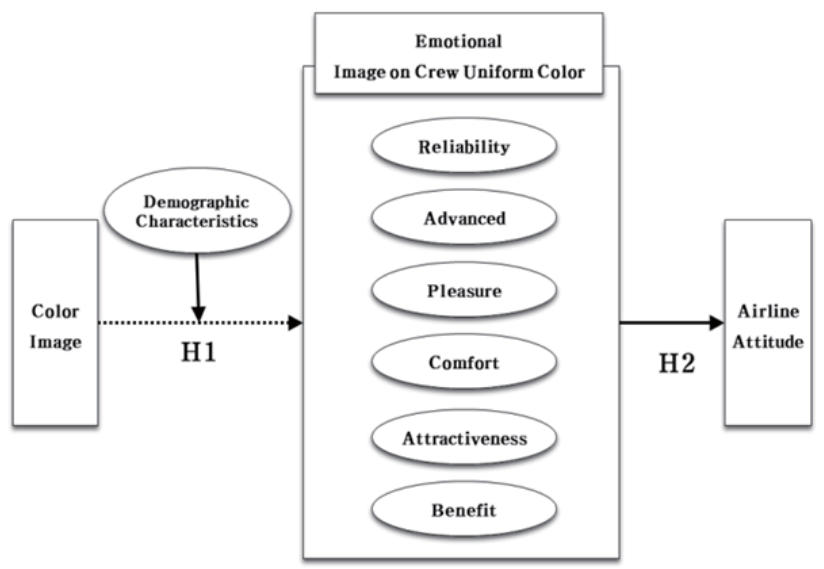

Figure 1: Research Model

Prior to the data collection for empirical analysis, the abstract concept was operationally defined so that it could be measured in order to increase the validity of the measurement tool.

\subsection{Sampling and Survey Methods}

The case study of this study is based on the analysis of the total number of existing large airlines (Korean Air, Asiana Airlines) and six low-cost airlines (T'way, Jin Air, Eastar Jet, Jeju Air, Air Busan, Air Seoul) were selected, and color sensibility adjectives required for empirical research were extracted based on the color image analysis results shown in visual identity elements among airline image attributes. Based on the adjective image scale developed by the IRI Color Research Institute with the support of the Ministry of Commerce, Industry and Energy, the color sensibility adjective presented color images according to the eight colors of airline to 15 color experts, only admirable adjectives were extracted.

\section{Empirical analysis}

\subsection{General characteristics of the sample}

The demographic characteristics of a total of 350 samples used in the empirical analysis. There were 213 women (60.9\%) and 137 men(39.1\%), and the distribution of women was $40.1 \%$ and $40.0 \%$ respectively. The number of officers was $179(21.1 \%), 60$ housewives $(17.1 \%)$, 33students $(9.4 \%)$ and 33self-employed people(9.4\%). In classification by purpose of travel, 261 people(74.6\%) were in sightseeing, 83 people(23.7\%) were in business and 6 were others (1.7\%).

\subsection{Color Image Preference by Demographic Characteristics}

$<$ Table 1> shows the favorability of airline uniform according to gender. For men, Korean Air's uniforms were the most favorable for the uniforms at 4.10 , followed by Jeju Air 3.52, Asiana Airlines 3.50, Eastar Jet 3.11, Air Seoul 3.09, T'way 3.07 and Jin Air 2.99. Women's favorite uniform colors were Korean Air's uniforms at 4.30, followed by Asiana Airlines 3.52, Jeju Air 3.44, Air Busan 3.25, Eastar Jet 3.14, Air Seoul 3.13, T'way 3.11 and Jin Air 2.82.

Table 1: Favorability to Crew Uniform Color by Gender

\begin{tabular}{|c|c|c|c|c|c|}
\hline Airline & Male & Female & Airline & Male & Female \\
\hline Korean Airline & 4.10 & 4.20 & Asiana Airline & 3.50 & 3.52 \\
\hline Jeju Air & 3.52 & 3.44 & Air Busan & 3.04 & 3.25 \\
\hline Eastar Jet & 3.11 & 3.14 & Air Seoul & 3.09 & 3.13 \\
\hline T'way Air & 3.07 & 3.11 & Jin Air & 2.99 & 2.82 \\
\hline
\end{tabular}

$<$ Table 2> shows the favorability of airline uniform according to age. In 20s, Korean Air's uniforms were the most favorable for the uniforms at 4.33 , followed by Asiana 
Airlines 4.28, Jeju Air 3.94, Air Seoul 3.72, T'way 3.67, Air Busan 3.47, Eastar Jet 3.47 and Jin Air 2.83. In 30s, Korean Air's uniform was the most favorable for the uniforms at 3.97, followed by Jeju Air 3.36, Asiana Airlines 3.23, Air Busan 3.15, T'way Air 3.00, Eastar Jet 2.87, Jin Air 2.77 and Air Seoul 2.74. In 40s, Korean Air's uniform was the most favorable for the uniforms of 4.38 , followed by Asiana Airlines 3.36, Jeju Air 3.36, Easatar Jet 3.20, T'way 3.06, Air Busan 3.06, Air Busan 2.98 and Jin Air 2.84. For those aged 50 and over, the likelihood of Korean Air's uniform was the highest at 4.23, followed by Asiana Airlines 3.85, Air Seoul 3.85, Jeju Air 3.54, Jin Air 3.46, Air Busan 3.23, Eastar Jet 3.01, and T'way 2.69.

Table 2: Favorability to Crew Uniform Color by Age

\begin{tabular}{|c|c|c|c|c|c|c|c|c|}
\hline & $\begin{array}{c}\text { Korean } \\
\text { Air }\end{array}$ & $\begin{array}{c}\text { Asiana } \\
\text { Air }\end{array}$ & T'way & $\begin{array}{c}\text { Jeju } \\
\text { Air }\end{array}$ & $\begin{array}{c}\text { Air } \\
\text { Busan }\end{array}$ & $\begin{array}{c}\text { Eastar } \\
\text { Jet }\end{array}$ & $\begin{array}{c}\text { Jin } \\
\text { Air }\end{array}$ & $\begin{array}{c}\text { Air } \\
\text { Seoul }\end{array}$ \\
\hline $20 \mathrm{~s}$ & 4.33 & 4.28 & 3.67 & 3.94 & 3.47 & 3.47 & 2.83 & 3.72 \\
\hline $30 \mathrm{~s}$ & 3.97 & 3.23 & 3.00 & 3.36 & 3.15 & 2.87 & 2.77 & 2.74 \\
\hline $40 \mathrm{~s}$ & 4.38 & 3.36 & 3.06 & 3.36 & 3.06 & 3.20 & 2.84 & 2.98 \\
\hline over50 & 4.23 & 3.85 & 2.69 & 3.54 & 3.23 & 3.01 & 3.46 & 3.85 \\
\hline
\end{tabular}

$<$ Table $3>$ shows the favorability of color image of airline uniform according to occupation. The average number of Korean Air's uniforms was 4.20, followed by Jeju Air 3.60, Asiana Airlines 3.36, T'way 3.25, Air Busan 3.18, East Air 3.07, Jin Air 3.01 and Air Seoul 2.92. Students had the highest likelihood of Asiana Airlines uniforms at 4.18. The self-employed showed the highest likelihood of Korean Air uniforms at 4.36, followed by Air Busan 3.55, Asiana Airlines 3.18, Air Seoul 3.00, Jin Air 2.64, T'way 2.00, and Eastar Jet 2.00. The housewives showed the highest likelihood of Korean Air's uniforms at 4.20, followed by Eastar Jet 3.40, Asiana Airline 3.35, T'way 3.30, Air Seoul 3.30, Air Busan 2.80, and Jin Air 2.70 respectively. The other groups showed the highest likelihood of Korean Air uniforms at 4.60, followed by Asiana Airlines 4.07, Jeju Air 3.80, Air Seoul 3.60, Air Busan 3.53, Eastar Jet 3.38, T'way 3.20 and Jin Air 3.20 .

Table 3: Favorability to Crew Uniform Color by Occupation

\begin{tabular}{|c|c|c|c|c|c|c|c|c|}
\hline & $\begin{array}{c}\text { Korean } \\
\text { Air }\end{array}$ & $\begin{array}{c}\text { Asiana } \\
\text { Air }\end{array}$ & $\begin{array}{c}\text { T'way } \\
\text { Air }\end{array}$ & $\begin{array}{c}\text { Jeju } \\
\text { Air }\end{array}$ & $\begin{array}{c}\text { Air } \\
\text { Busan }\end{array}$ & $\begin{array}{c}\text { Eastar } \\
\text { Jet }\end{array}$ & $\begin{array}{c}\text { Jin } \\
\text { Air }\end{array}$ & $\begin{array}{c}\text { Air } \\
\text { Seoul }\end{array}$ \\
\hline Officer & 4.20 & 3.36 & 3.25 & 3.60 & 3.18 & 3.07 & 3.01 & 2.92 \\
\hline Student & 3.73 & 4.18 & 2.82 & 3.64 & 2.91 & 3.82 & 2.36 & 3.82 \\
\hline $\begin{array}{c}\text { Self- } \\
\text { employed }\end{array}$ & 4.36 & 3.18 & 2.00 & 3.00 & 3.55 & 2.00 & 2.64 & 3.00 \\
\hline Hosewife & 4.20 & 3.35 & 3.30 & 3.00 & 2.80 & 3.40 & 2.70 & 3.00 \\
\hline Others & 4.60 & 4.07 & 3.20 & 3.80 & 3.53 & 3.38 & 3.20 & 3.60 \\
\hline
\end{tabular}

$<$ Table 4> shows the favorable attitude of color images of airline uniforms according to the biggest purpose of getting on airplanes. Korean Air's average of 4.39 was the most favored for Korean Air's uniforms, with 3.86 for Jeju Air, 3.60 for Asiana Airlines, 3.45 for Air Busan, 3.22 for T'way Air, 3.17 for Jin Air, 3.09 for Air Seoul 3.04 in that order. The average number of passengers on the plane for the purpose of sightseeing trip was the highest of 4.17 for Korean Air uniforms. The average was 4.17 for Asiana Airlines, 3.49 for Jeju Air, 3.36 for Air, 3.13 for Air, 3.13 for Air, 3.09 for Air Busan, Jin Air 2.82 in order. The other groups showed the highest likelihood of Korean Air, T'way Air and Eastar airliners at 4.00, followed by Asiana Airlines 3.00, Jeju Air 3.00, Air Busan 3.00, Jin Air 2.00 and Air Seoul 2.00.

Table 4: Favorability to Crew Uniform Color by Purpose of Travel

\begin{tabular}{|c|c|c|c|c|c|c|c|c|}
\hline & $\begin{array}{c}\text { Korean } \\
\text { Air }\end{array}$ & $\begin{array}{c}\text { Asiana } \\
\text { Air }\end{array}$ & $\begin{array}{c}\text { Tway } \\
\text { Air }\end{array}$ & $\begin{array}{c}\text { Jeju } \\
\text { Air }\end{array}$ & $\begin{array}{c}\text { Air } \\
\text { Busan }\end{array}$ & $\begin{array}{c}\text { Eastar } \\
\text { Jet }\end{array}$ & $\begin{array}{c}\text { Jin } \\
\text { Air }\end{array}$ & $\begin{array}{c}\text { Air } \\
\text { Seoul }\end{array}$ \\
\hline $\begin{array}{c}\text { Business } \\
\text { Trip }\end{array}$ & 4.39 & 3.60 & 3.22 & 3.86 & 3.45 & 3.09 & 3.17 & 3.04 \\
\hline Travel & 4.17 & 3.49 & 3.03 & 3.36 & 3.09 & 3.13 & 2.82 & 3.16 \\
\hline Others & 4.00 & 3.00 & 4.00 & 3.00 & 3.00 & 4.00 & 2.00 & 2.00 \\
\hline
\end{tabular}

$<$ Table 5> shows the favorable attitude of color images according to the number of domestic travel flights. The average number of passengers who used domestic travel flights was 1.33, which was the highest on Korean Air's average of 4.33. Jeju Air 3.67, Air Bus 3.67, Jin Air 3.33, T'way Air 3.00, Asiana 2.67, and Air Seoul 2.33. The average number of passengers in the 3rd and 4th groups was 4.56, which was the highest in Korean Air uniforms at 4.56, followed by Jeju Air 3.56, Jin 3.56, Eastar Jet 3.29, Air Seoul 3.29, Asiana Airlines 3.20, appear. In the groups 5 6 , the favorability of Korean Air uniforms was the highest at 3.93, with Asiana Airlines 3.40, Jeju Air 3.40, Teai Air 3.20, East Air 3.13, Jin Air 3.07, Air Busan 2.93 and Air Seoul 2.67 appear. In the groups 7 to 8 , Korean Air had the highest average of 4.56 on average, followed by Asiana Airlines 4.33, Jeju Air 4.11, Air Seoul 4.11, T'way Air 3.89, Air Bus 3.67, Jin Air 3.67, and Eastar Jet 3.00 appear. Finally, the group of 9 or more had the highest likelihood of Korean Air uniforms at 4.16, followed by Asiana Airlines 3.56, Jeju Air 3.37, Eastar Jet 3.18, Air Busan 3.16, Air Seoul 3.11, T'way Air 2.97, Jin Air 2.59 respectively.

Table 5: Favorability to Crew Uniform Color by Frequency of Domestic flight

\begin{tabular}{|c|c|c|c|c|c|c|c|c|}
\hline & $\begin{array}{c}\text { Korean } \\
\text { Air }\end{array}$ & $\begin{array}{c}\text { Asiana } \\
\text { Air }\end{array}$ & $\begin{array}{c}\text { T'way } \\
\text { Air }\end{array}$ & $\begin{array}{c}\text { Jeju } \\
\text { Air }\end{array}$ & $\begin{array}{c}\text { Air } \\
\text { Busan }\end{array}$ & $\begin{array}{c}\text { Eastar } \\
\text { Jet }\end{array}$ & $\begin{array}{c}\text { Jin } \\
\text { Air }\end{array}$ & $\begin{array}{c}\text { Air } \\
\text { Seoul }\end{array}$ \\
\hline $\begin{array}{c}1 \sim 2 \\
\text { times }\end{array}$ & 4.33 & 2.67 & 3.00 & 3.67 & 3.67 & 2.33 & 3.33 & 2.33 \\
\hline $\begin{array}{c}3 \sim 4 \\
\text { times }\end{array}$ & 4.56 & 3.20 & 3.15 & 3.56 & 3.00 & 3.29 & 3.56 & 3.29 \\
\hline $\begin{array}{c}5 \sim 6 \\
\text { times }\end{array}$ & 3.93 & 3.40 & 3.20 & 3.40 & 2.93 & 3.13 & 3.07 & 2.67 \\
\hline $\begin{array}{c}7 \sim 8 \\
\text { times }\end{array}$ & 4.56 & 4.33 & 3.89 & 4.11 & 3.67 & 3.00 & 3.67 & 4.11 \\
\hline $\begin{array}{c}\text { Over } \\
9\end{array}$ & 4.16 & 3.56 & 2.97 & 3.37 & 3.16 & 3.18 & 2.59 & 3.11 \\
\hline
\end{tabular}


$<$ Table 6> shows the favorability of the color image according to the frequency of use of overseas travel flights. The average number of passengers who traveled overseas was 1 or 2 times. The average of Korean Air's uniforms was 5.00, which was the highest. The average was 5.00. Asiana Airlines 4.00, T'way Air 4.00, Jeju Air 4.00, Air Busan 4.00, and Air Seoul 3.00. The average number of passengers in the 3rd and 4th groups was 4.40, which was the highest among Korean Air's uniforms. The average was 4.40, followed by Asiana Airlines 3.70, Jeju Air 3.70, Air Bus 3.30, Jin Air 3.10, appear. For the groups 5 6, Korean Air and Asiana Airlines had the highest favorability for uniforms of 3.50, followed by Jeju Air 3.20, Air Busan 3.20, T'way Air 3.00, Eastar Jet 3.00, Air Seoul 2.80, and Jin Air 2.10. In the groups 7 8, Korean Air had the highest likelihood of uniforms of 4.00, followed by Asiana Airlines 3.00, Jeju Air 3.00, Air Busan 3.00, Jin Air 3.00, Air Seoul 3.00, T'way Air 2.33, and Eastar Jet 2.33 appear. Lastly, Korean Air has the highest average of 4.27 for Korean Air uniforms, with the average of 4.27 for Asiana Airlines 3.50, Jeju Air 3.48, East Air 3.19, Air Seoul 3.16, Air Busan 3.14, T'way Air 3.12 and Jin Air 2.95 respectively.

Table 6: Favorability to Crew Uniform Color by Frequency of Overseas Travel Flight

\begin{tabular}{|c|c|c|c|c|c|c|c|c|}
\hline & $\begin{array}{c}\text { Korean } \\
\text { Air }\end{array}$ & $\begin{array}{c}\text { Asiana } \\
\text { Air }\end{array}$ & $\begin{array}{c}\text { T'way } \\
\text { Air }\end{array}$ & $\begin{array}{c}\text { Jeju } \\
\text { Air }\end{array}$ & $\begin{array}{c}\text { Air } \\
\text { Busan }\end{array}$ & $\begin{array}{c}\text { Eastar } \\
\text { Jet }\end{array}$ & $\begin{array}{c}\text { Jin } \\
\text { Air }\end{array}$ & $\begin{array}{c}\text { Air } \\
\text { Seoul }\end{array}$ \\
\hline $\begin{array}{c}1 \sim 2 \\
\text { times }\end{array}$ & 5.00 & 4.00 & 4.00 & 4.00 & 4.00 & 3.00 & 3.00 & 3.00 \\
\hline $\begin{array}{c}3 \sim 4 \\
\text { times }\end{array}$ & 4.40 & 3.70 & 3.00 & 3.70 & 3.30 & 3.00 & 3.10 & 3.00 \\
\hline $\begin{array}{c}5 \sim 6 \\
\text { times }\end{array}$ & 3.50 & 3.50 & 3.00 & 3.20 & 3.20 & 3.00 & 2.10 & 2.80 \\
\hline $\begin{array}{c}7 \sim 8 \\
\text { times }\end{array}$ & 4.00 & 3.00 & 2.33 & 3.00 & 3.00 & 2.33 & 3.00 & 3.00 \\
\hline $\begin{array}{c}\text { Over } \\
9\end{array}$ & 4.27 & 3.50 & 3.12 & 3.48 & 3.14 & 3.19 & 2.95 & 3.16 \\
\hline
\end{tabular}

\subsection{Relationship between Airline's Emotional Image and Customer attitude}

\subsubsection{Korean Air}

The results of multiple regression analysis on the effect of Korean air use emotional image on airline's customer attitude were as shown in $<$ Table $7>$. First, the explanatory power of sub-factors of emotional image on airline loyalty was $63.6 \%$ and $F=102.587(p=.000)$. The effect of reliability, advanced, pleasure, comfort, and attractiveness on airline affection was $0.147(\mathrm{t}=2.658, \mathrm{p}=.008), \quad 0.176(\mathrm{t}=3.386$, $\mathrm{p}=.001), 0.242(\mathrm{t}=5.217, \mathrm{p}=.000), 0.401(\mathrm{t}=7.024, \mathrm{p}=.000)$, $0.146(\mathrm{t}=2.450, \mathrm{p}=.015)$, respectively. This showed $\mathrm{a}$ statistically significant effect. The effect of benefits on airline's customer attitude was $-0.076(t=-1.556, p=.121)$, showing no statistically significant effect.

\subsubsection{Asiana Airline}

A multiple regression analysis of the effect of Asiana airline emotional image on airline's customer attitude is shown in <Table 8>. First, the explanatory power of subfactors of emotional image on airline affection was $80.8 \%$ and $\mathrm{F}=241.998(\mathrm{p}=.000)$.

On the other hand, the effects of subordinate factors of emotional image on airline customer attitude such as reliability, advanced, pleasure, comfort, attractiveness and benefit were 0.403(t=8.587, $\mathrm{p}=.000), 0.185(\mathrm{t}=4.999, \mathrm{p}=.000)$, $0.157(\mathrm{t}=3.614, \mathrm{p}=.000), 0.437(\mathrm{t}=11.587, \mathrm{p}=.000), 0.147$ $(\mathrm{t}=3.839, \mathrm{p}=.000), 0.130(\mathrm{t}=2.872, \mathrm{p}=.004)$, Indicating $\mathrm{a}$ statistically significant effect.

Table 7: The Relationship between Emotional Image and Attitude of Korean Air Uniform

\begin{tabular}{|c|c|c|c|c|c|c|c|c|}
\hline \multirow{2}{*}{$\begin{array}{l}\text { Independent } \\
\text { Variable }\end{array}$} & \multirow{2}{*}{$\begin{array}{l}\text { Dependent } \\
\text { Variable }\end{array}$} & \multicolumn{2}{|c|}{ Non-standardized Factor } & \multirow{2}{*}{$\begin{array}{c}\text { S.F } \\
\beta\end{array}$} & \multirow{2}{*}{ t-value } & \multirow{2}{*}{$p$-value } & \multirow{2}{*}{ VIF } & \multirow{2}{*}{ Note } \\
\hline & & B & S.E & & & & & \\
\hline (Constant) & \multirow{7}{*}{$\begin{array}{l}\text { Airline } \\
\text { Attitude }\end{array}$} & -.285 & .191 & & -1.497 & .135 & & \multirow{7}{*}{$\begin{array}{c}R^{2}=.642 \\
\text { Adj- } R^{2}=.636 \\
F=102.587 \\
(p=.000)\end{array}$} \\
\hline reliability & & .147 & .055 & .146 & 2.658 & .008 & $\begin{array}{c}.342 \\
(2.880)\end{array}$ & \\
\hline advanced & & .176 & .052 & .179 & 3.386 & .001 & $\begin{array}{c}.372 \\
(2.691)\end{array}$ & \\
\hline Pleasure & & .242 & .046 & .265 & 5.217 & .000 & $\begin{array}{c}.405 \\
(2.466)\end{array}$ & \\
\hline Comfort & & .401 & .057 & .307 & 7.024 & .000 & $\begin{array}{c}.547 \\
(1.830)\end{array}$ & \\
\hline Attractiveness & & .146 & .059 & .137 & 2.450 & .015 & $\begin{array}{c}.336 \\
(2.980)\end{array}$ & \\
\hline Benefit & & -.076 & .049 & -.068 & -1.556 & .121 & $\begin{array}{c}.545 \\
(1.836)\end{array}$ & \\
\hline
\end{tabular}


Table 8: The Relationship between Emotional Image and Attitude of Asian Airline Uniform

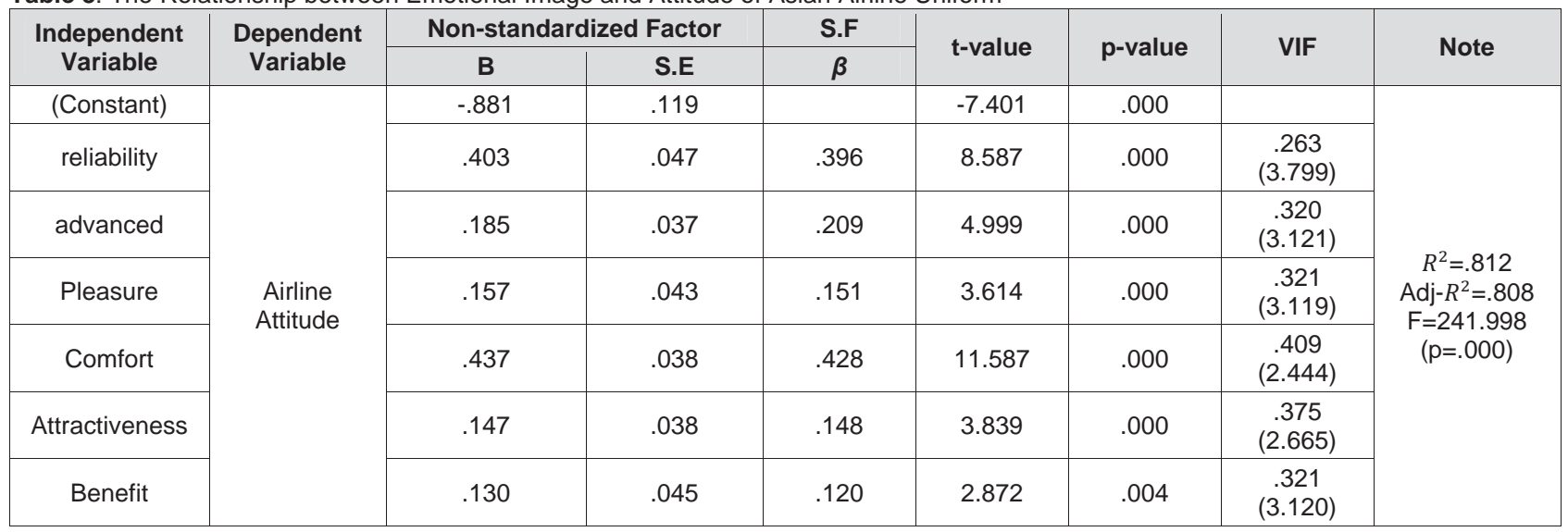

Table 9: The Relationship between Emotional Image and Attitude of T'way Uniform

\begin{tabular}{|c|c|c|c|c|c|c|c|c|}
\hline \multirow{2}{*}{$\begin{array}{l}\text { Independent } \\
\text { Variable }\end{array}$} & \multirow{2}{*}{$\begin{array}{l}\text { Dependent } \\
\text { Variable }\end{array}$} & \multicolumn{2}{|c|}{ Non-standardized Factor } & \multirow{2}{*}{$\begin{array}{c}\text { S.F } \\
\beta\end{array}$} & \multirow{2}{*}{ t-value } & \multirow{2}{*}{ p-value } & \multirow{2}{*}{ VIF } & \multirow{2}{*}{ Note } \\
\hline & & B & S.E & & & & & \\
\hline (Constant) & \multirow{7}{*}{$\begin{array}{l}\text { Airline } \\
\text { Attitude }\end{array}$} & .120 & .094 & & 1.283 & .200 & & \multirow{7}{*}{$\begin{array}{l}R^{2}=.819 \\
\text { Adj- } R^{2}=.815 \\
\mathrm{~F}=253.516 \\
(\mathrm{p}=.000)\end{array}$} \\
\hline reliability & & -.014 & .038 & -.013 & -.353 & .725 & $\begin{array}{c}.371 \\
(2.696) \\
\end{array}$ & \\
\hline advanced & & .293 & .028 & .350 & 10.427 & .000 & $\begin{array}{c}.477 \\
(2.096)\end{array}$ & \\
\hline Pleasure & & .026 & .026 & .028 & .979 & .328 & $\begin{array}{c}.660 \\
(1.515) \\
\end{array}$ & \\
\hline Comfort & & .260 & .034 & .279 & 7.588 & .000 & $\begin{array}{c}.399 \\
(2.508) \\
\end{array}$ & \\
\hline Attractiveness & & .071 & .036 & .073 & 1.973 & .049 & $\begin{array}{c}.390 \\
(2.566)\end{array}$ & \\
\hline Benefit & & .280 & .031 & .356 & 9.097 & .000 & $\begin{array}{c}.352 \\
(2.843)\end{array}$ & \\
\hline
\end{tabular}

\subsubsection{T'way}

As shown in $\langle$ Table 9>, multiple regression analysis of the effect of the emotional image on airline customer attitude was shown. First, the explanatory power of subfactors of emotional image on airline affection was $81.5 \%$ and $F=253.516(p=.000)$.

On the other hand, the effects of advanced, comfort, attractiveness, and profitability on airline affection were 0.293 $(t=10.427, \quad p=.000), \quad 0.260(t=7.588, \quad p=.000)$, 0.071 ( $\mathrm{t}=1.973, \mathrm{p}=.049), 0.280(\mathrm{t}=9.097, \mathrm{p}=.000)$, respectively, indicating a statistically significant effect. The impact of reliability and pleasure on airline appeal is $-0.014(\mathrm{t}=-) .353$, $\mathrm{p}=.725), \quad 0.026(\mathrm{t}=.979, \mathrm{p}=.328)$ showing no statistically significant effect. The impact of reliability and pleasure on airline customer loyalty is $-0.014(\mathrm{t}=-.353, \mathrm{p}=.725), 0.026$ $(t=.979, p=.328)$ showing no statistically significant effect.

\subsubsection{Jeju Air}

A multi-regression analysis of the impact of Jeju Air's emotional image on airline attitude has shown in $<$ Table 10$\rangle$. First, the explanatory power of sub-factors of the emotional image of airlines' attitude was shown to be $72.0 \%$ and as $F=15.897(p=.000)$, which was statistically significant. On the other hand, among the sub-factors of emotional image, the impact of reliability, advanced, pleasure, comfort and benefits on airline appeal is $0.280(t=5.142, p=.000)$, 0.297(t=7.258, $\quad \mathrm{p}=.000), \quad 0.115(\mathrm{t}=2.922, \quad \mathrm{p}=.004)$, $0.105(\mathrm{t}=2.348, \quad \mathrm{p}=.019), \quad 0.230(\mathrm{t}=5.362, \mathrm{p}=.000)$ has $\mathrm{a}$ statistically significant effect. The effect of attractiveness on airline appeal is $0.051(\mathrm{t}=1.040, \mathrm{p}=299)$ appears to have no statistically significant effect. The effect of attractiveness on airline customer attitude is $0.051(\mathrm{t}=1.040, \mathrm{p}=299)$ appears to have no statistically significant effect. 
Table 10: The Relationship between Emotional Image and Attitude of Jeju Air Uniform

\begin{tabular}{|c|c|c|c|c|c|c|c|c|}
\hline \multirow{2}{*}{$\begin{array}{c}\text { Independent } \\
\text { Variable }\end{array}$} & \multirow{2}{*}{$\begin{array}{l}\text { Dependent } \\
\text { Variable }\end{array}$} & \multicolumn{2}{|c|}{ Non-standardized Factor } & \multirow{2}{*}{$\begin{array}{c}\text { S.F } \\
\beta\end{array}$} & \multirow{2}{*}{ t-value } & \multirow{2}{*}{ p-value } & \multirow{2}{*}{ VIF } & \multirow{2}{*}{ Note } \\
\hline & & B & S.E & & & & & \\
\hline (Constant) & \multirow{7}{*}{$\begin{array}{l}\text { Airline } \\
\text { Attitude }\end{array}$} & -.394 & .123 & & -3.207 & .001 & & \multirow{7}{*}{$\begin{array}{l}R^{2}=.725 \\
\text { Adj- } R^{2}=.720 \\
\mathrm{~F}=150.897 \\
(\mathrm{p}=.000)\end{array}$} \\
\hline reliability & & .280 & .055 & .229 & 5.142 & .000 & $\begin{array}{c}.405 \\
(2.471)\end{array}$ & \\
\hline advanced & & .297 & .041 & .296 & 7.258 & .000 & $\begin{array}{c}.482 \\
(2.075)\end{array}$ & \\
\hline Pleasure & & .115 & .040 & .126 & 2.922 & .004 & $\begin{array}{c}.429 \\
(2.331)\end{array}$ & \\
\hline Comfort & & .105 & .045 & .106 & 2.348 & .019 & $\begin{array}{c}.390 \\
(2.562)\end{array}$ & \\
\hline Attractiveness & & .051 & .049 & .052 & 1.040 & .299 & $\begin{array}{c}.326 \\
(3.068)\end{array}$ & \\
\hline Benefit & & .230 & .043 & .235 & 5.362 & .000 & $\begin{array}{c}.417 \\
(2.399)\end{array}$ & \\
\hline
\end{tabular}

Table 11: The Relationship between Emotional Image and Attitude of Air Busan Uniform

\begin{tabular}{|c|c|c|c|c|c|c|c|c|}
\hline \multirow{2}{*}{$\begin{array}{c}\text { Independent } \\
\text { Variable }\end{array}$} & \multirow{2}{*}{$\begin{array}{l}\text { Dependent } \\
\text { Variable }\end{array}$} & \multicolumn{2}{|c|}{ Non-standardized Factor } & \multirow{2}{*}{$\begin{array}{c}\text { S.F } \\
\beta\end{array}$} & \multirow{2}{*}{ t-value } & \multirow{2}{*}{ p-value } & \multirow{2}{*}{ VIF } & \multirow{2}{*}{ Note } \\
\hline & & B & S.E & & & & & \\
\hline (Constant) & \multirow{7}{*}{$\begin{array}{l}\text { Airline } \\
\text { Attitude }\end{array}$} & -.279 & .099 & & -2.813 & .005 & & \multirow{7}{*}{$\begin{array}{l}R^{2}=811 \\
\text { Adj- } R^{2}=.807 \\
\mathrm{~F}=244.598 \\
(\mathrm{p}=.000)\end{array}$} \\
\hline reliability & & .499 & .049 & .560 & 10.246 & .000 & $\begin{array}{c}.185 \\
(5.401)\end{array}$ & \\
\hline advanced & & .012 & .035 & .012 & .350 & .726 & $\begin{array}{c}.436 \\
(2.294)\end{array}$ & \\
\hline Pleasure & & .257 & .031 & .278 & 8.351 & .000 & $\begin{array}{c}.499 \\
(2.004)\end{array}$ & \\
\hline Comfort & & -.062 & .053 & -.059 & -1.171 & .242 & $\begin{array}{c}.215 \\
(4.648)\end{array}$ & \\
\hline Attractiveness & & -.005 & .037 & -.005 & -.131 & .896 & $\begin{array}{c}.378 \\
(2.645) \\
\end{array}$ & \\
\hline Benefit & & .297 & .042 & .250 & 7.014 & .000 & $\begin{array}{c}.435 \\
(2.297)\end{array}$ & \\
\hline
\end{tabular}

\subsubsection{Air Busan}

A multi-regression analysis of the impact of Air Busan's emotional image on airline customer attitude has shown in $<$ Table 11>. First, the explanatory power of sub-factors of the emotional image of airlines' customer attitude was shown to be $80.7 \%$, and to be statistically significant, with $F=244.598(p=.000)$. On the other hand, the impact of reliability, pleasure and benefits on airline appeal among sub-factors of emotional image is $.499(t=10.246, p=.000)$, 0.257( $\mathrm{t}=8.351, \mathrm{p}=.000), 0.297(\mathrm{t}=7.014, \mathrm{p}=.004)$ appears to have a statistically significant effect, and the impact of advanced, comfort and attractiveness on airline customer attitude is $0.012(t=.350, p=.726),-0.062(t=-1.171, p=.242)$, 0.005( $\mathrm{t}=-.131, \mathrm{p}=.896)$, showing no statistically significant effect.

\subsubsection{Eastar Jet}

A multi-regression analysis of the impact of Eastar Jet's emotional image on airline's customer attitude has shown in $<$ Table 12>. First, the explanatory power of sub-factors of the emotional image of airlines' customer attitude was shown to be $80.6 \%$, and to be statistically significant, with $F=238.792(p=.000)$. On the other hand, the sub-factors of emotional image have the effect of reliability $0.228(t=5.257$, $\mathrm{p}=.000)$, advanced 0.251( $\mathrm{t}=6.481, \mathrm{p}=.000)$, comfort $0.130(\mathrm{t}=2.667, \mathrm{p}=.008)$ and attractiveness $0.438(\mathrm{t}=7.139$, $\mathrm{p}=.000)$ on airline customer loyalty. The impact of pleasure $(-0.074(t=-1.663, \quad p=.097)) \quad$ and benefits $(0.073(t=1.550, p=.112))$ on Airline's Affection was found to have no significant. 
Table 12: The Relationship between Emotional Image and Attitude of Eastar Jet Uniform

\begin{tabular}{|c|c|c|c|c|c|c|c|c|}
\hline \multirow{2}{*}{$\begin{array}{l}\text { Independent } \\
\text { Variable }\end{array}$} & \multirow{2}{*}{$\begin{array}{l}\text { Dependent } \\
\text { Variable }\end{array}$} & \multicolumn{2}{|c|}{ Non-standardized Factor } & \multirow{2}{*}{$\begin{array}{c}\text { S.F } \\
\beta\end{array}$} & \multirow{2}{*}{ t-value } & \multirow{2}{*}{ p-value } & \multirow{2}{*}{ VIF } & \multirow{2}{*}{ Note } \\
\hline & & B & S.E & & & & & \\
\hline (Constant) & \multirow{7}{*}{$\begin{array}{l}\text { Airline } \\
\text { Attitude }\end{array}$} & .425 & .112 & & 3.808 & .000 & & \multirow{7}{*}{$\begin{array}{l}R^{2}=.810 \\
\text { Adj- } R^{2}=.806 \\
\mathrm{~F}=238.792 \\
(\mathrm{p}=.000)\end{array}$} \\
\hline reliability & & .228 & .043 & .221 & 5.257 & .000 & $\begin{array}{c}.319 \\
(3.136)\end{array}$ & \\
\hline advanced & & .251 & .039 & .329 & 6.481 & .000 & $\begin{array}{c}.219 \\
(4.567) \\
\end{array}$ & \\
\hline Pleasure & & -.074 & .045 & -.057 & -1.663 & .097 & $\begin{array}{c}.475 \\
(2.106) \\
\end{array}$ & \\
\hline Comfort & & .130 & .049 & .089 & 2.667 & .008 & $\begin{array}{c}.507 \\
(1.970) \\
\end{array}$ & \\
\hline Attractiveness & & .438 & .061 & .446 & 7.139 & .000 & $\begin{array}{c}.144 \\
(6.921) \\
\end{array}$ & \\
\hline Benefit & & .073 & .047 & .072 & 1.550 & .122 & $\begin{array}{c}.261 \\
(3.825)\end{array}$ & \\
\hline
\end{tabular}

Table 13: The Relationship between Emotional Image and Attitude of Jin Air Uniform

\begin{tabular}{|c|c|c|c|c|c|c|c|c|}
\hline \multirow{2}{*}{$\begin{array}{l}\text { Independent } \\
\text { Variable }\end{array}$} & \multirow{2}{*}{$\begin{array}{l}\text { Dependent } \\
\text { Variable }\end{array}$} & \multicolumn{2}{|c|}{ Non-standardized Factor } & \multirow{2}{*}{$\begin{array}{c}\text { S.F } \\
\beta\end{array}$} & \multirow{2}{*}{ t-value } & \multirow{2}{*}{ p-value } & \multirow{2}{*}{ VIF } & \multirow{2}{*}{ Note } \\
\hline & & B & S.E & & & & & \\
\hline (Constant) & \multirow{7}{*}{$\begin{array}{l}\text { Airline } \\
\text { Attitude }\end{array}$} & .462 & .119 & & 3.898 & .000 & & \multirow{7}{*}{$\begin{array}{l}R^{2}=.727 \\
\text { Adj- } R^{2}=.722 \\
\mathrm{~F}=149.828 \\
(\mathrm{p}=.000)\end{array}$} \\
\hline reliability & & .249 & .048 & .297 & 5.203 & .000 & $\begin{array}{c}.248 \\
(4.034)\end{array}$ & \\
\hline advanced & & .192 & .039 & .244 & 4.956 & .000 & $\begin{array}{c}.335 \\
(2.987)\end{array}$ & \\
\hline Pleasure & & .191 & .038 & .214 & 5.050 & .000 & $\begin{array}{c}.452 \\
(2.210) \\
\end{array}$ & \\
\hline Comfort & & .265 & .064 & .195 & 4.133 & .000 & $\begin{array}{c}.364 \\
(2.749)\end{array}$ & \\
\hline Attractiveness & & .152 & .058 & .156 & 2.611 & .009 & $\begin{array}{c}.227 \\
(4.413)\end{array}$ & \\
\hline Benefit & & .278 & .061 & .258 & 4.529 & .000 & $\begin{array}{c}.249 \\
(4.024)\end{array}$ & \\
\hline
\end{tabular}

\subsubsection{Jin Air}

A multi-return analysis of Jin-Air's emotional image on airline attitude has shown in <Table 13>. First, the explanatory power of sub-factors of the emotional image of airlines' attitude was shown to be $72.2 \%$ and as $\mathrm{F}=149.828(\mathrm{p}=.000)$, which is statistically significant. On the other hand, the impact of reliability, advanced, pleasure, comfort, attractiveness, and benefits on airline customer loyalty, respectively, sub-factors of emotional image are $0.249(\mathrm{t}=5.230, \quad \mathrm{p}=.000), \quad 0.192(\mathrm{t}=4.956, \quad \mathrm{p}=.000), \quad 0.191$ $(\mathrm{t}=5.050, \mathrm{p}=.008), 0.265(\mathrm{t}=4.133, \mathrm{p}=.000), 0.152(\mathrm{t}=2.611$, $\mathrm{p}=.009), \quad 0.278(\mathrm{t}=4.529, \quad \mathrm{p}=.000)$ respectively have a statistically significant effect.

\subsubsection{Air Seoul}

A multiple-regression analysis of the impact of Air Seoul's emotional image on airline customer attitude has shown in $<$ Table 14>. First, the explanatory power of sub-factors of the emotional image of airlines' customer attitude was shown to be $74.5 \%$ and to be statistically significant, with $F=166.97(p=.000)$. On the other hand, among the subfactors of emotional image, the impact of advanced, pleasure, comfort, attractiveness and benefits on airline customer attitude are 0.276(t=7.645, $\mathrm{p}=.000), 0.139(\mathrm{t}=4.006$, $\mathrm{p}=.000), 0.097(\mathrm{t}=2.034, \mathrm{p}=.043), 0.140(\mathrm{t}=3.357, \mathrm{p}=.001)$, $0.195(\mathrm{t}=4.644, \mathrm{p}=.000)$ respectively have a statistically significant effect. 
Table 14: The Relationship between Emotional Image and Attitude of Air Seoul Uniform

\begin{tabular}{|c|c|c|c|c|c|c|c|c|}
\hline \multirow{2}{*}{$\begin{array}{l}\text { Independent } \\
\text { Variable }\end{array}$} & \multirow{2}{*}{$\begin{array}{l}\text { Dependent } \\
\text { Variable }\end{array}$} & \multicolumn{2}{|c|}{ Non-standardized Factor } & \multirow{2}{*}{$\begin{array}{c}\text { S.F } \\
\beta\end{array}$} & \multirow{2}{*}{ t-value } & \multirow{2}{*}{$p$-value } & \multirow{2}{*}{ VIF } & \multirow{2}{*}{ Note } \\
\hline & & B & S.E & & & & & \\
\hline (Constant) & \multirow{7}{*}{$\begin{array}{l}\text { Airline } \\
\text { Attitude }\end{array}$} & .076 & .101 & & .750 & .454 & & \multirow{7}{*}{$\begin{array}{l}R^{2}=.750 \\
\text { Adj- }-R^{2}=.745 \\
F=166.976 \\
(p=.000)\end{array}$} \\
\hline reliability & & .073 & .045 & .089 & 1.625 & .105 & $\begin{array}{c}.251 \\
(3.989)\end{array}$ & \\
\hline advanced & & .276 & .036 & .357 & 7.645 & .000 & $\begin{array}{c}.344 \\
(2.905)\end{array}$ & \\
\hline Pleasure & & .139 & .035 & .151 & 4.006 & .000 & $\begin{array}{c}.528 \\
(1.895)\end{array}$ & \\
\hline Comfort & & .097 & .048 & .090 & 2.034 & .043 & $\begin{array}{c}.385 \\
(2.595)\end{array}$ & \\
\hline Attractiveness & & .140 & .042 & .166 & 3.357 & .001 & $\begin{array}{c}.307 \\
(3.260)\end{array}$ & \\
\hline Benefit & & .195 & .042 & .222 & 4.644 & .000 & $\begin{array}{c}.329 \\
(3.043)\end{array}$ & \\
\hline
\end{tabular}

\section{Research Results and Discussion}

This study wanted to find out how cognitive perception of the uniform color of airline room passengers affects airline, and to make an empirical analysis of the impact of cognitive recognition on airline uniform color on airline's favorable attitude.

The empirical analysis results for the study showed a significant positive impact on the cognitive image of the uniform color, on the reliability, advanced, enjoyment, comfort, attractiveness and benefits of the uniform color in the impact of the cognitive image on the favorability of the airline passenger's uniform color. This means customers will have a cognitive image of the color of the uniforms they recognize, a reliable and professional feel for the crew. Recently, other service industries are recognizing the importance of uniforms and applying various uniform colors to uniforms that fit the identity of each company. Thus, the uniform is based on the professional feelings of the crew and the corporate identity. In other words, in airline uniform color, customers will have cognitive images such as reliability, advanced, enjoyment, comfort, attractiveness and benefits.

Second, the color image of the flight attendant had a significant positive effect on the airline's cognitive perception. This shows that when passengers think of an airline, they come up with a cognitive image of the airline about its uniform color image.

Third, it has been shown that the cognitive image on the color image of the crew has a significant positive effect on the airline's favoritism. This means that the more positive the customer's cognitive image of the airline's uniform color and airline's attitude. The following are to explore the academic and practical contributions of this study. First of all, from the academic point of view, specific factors about the color image of the crew were revealed through empirical analysis. They also found that the color images of airline flight attendants affect the cognitive image. This is the empirical support of Feldman (2001)'s work and the prior work of Aronson, Wilson, and Akert (2005). Also, the results of cognitive perception of airline uniform color images have an impact on airline popularity support existing studies.

\section{Research Limitations}

While the results of this study have academic and practical contributions, there are several limitations of the study: First, the results could be more reliable if the number of populations was increased in future studies, since all passengers of airlines were not eligible for the demonstration and samples were selected. In addition, pictures of the questionnaire to investigate the airline's color image used pictures of flight attendants in airline uniforms, so the respondents may have assessed factors other than the color of the airline's uniform emotionally. Further research suggests that supplementing these limitations will produce a wide range of meaningful results that will enhance the airline's cognitive image and affection.

\section{References}

Aaker, D. (1991). Managing Brand Equity; Capitalizing on the Value of a Brand Name. New York, NY: The Free Press.

Aronson, E., Wilson, T. D., \& Akert, R. (2005). Social Psychology ( $5^{\text {th }}$ ed.). New York, NY: Prentice.

Back, K-J. (2005). The Effects of Image Congruence on Customers' Brand Loyalty in the Upper Middle Class Hotel 
Industry. Journal of Hospitality \& Tourism Research, 29(4), 448-467. DOI: 10.1177/1096348005276497

Choi, N. H., \& Bae, G. C. (1999). A Study on the Relationship between Travel Service Image and Customer Loyalty. Tourism Studies, 22(3), 179-201.

Feldman, J. (2001). Bayesian Contour Integration. Percept and Psychophysics, 63(7), 1171-1182.

Ha, H. Y. (2010). Understanding Brand Image and Brand Affinity. Journal of Consumer Studies, 21(4), 23-42.

Ishaq, M. I. (2012). Perceived value, service quality, corporate Image and customer loyalty: Empirical assessment from Pakistan. Serbian Journal of Management, 7(1), 25-36.

Jee, G. W., Yoo, S. D., \& Han, J. Y. (2013). The Influence of Brand Image on Perceptual Values and Brand Affinity in a Special Hotel. Journal of Hospitality and Tourism, 15(2), 216-231.

Jeon, D. Y., Kwon, J. H., \& Kim, J. W. (2009). A Study on the Relative Influence of Store Personality and Functional Store Image on Store Affections. Journal of Marketing Management, 14(1), 99-127.

Kim, D. H., HA, J. Y., \& An, W. H. (2014). Mediation of Production Trust on Brand Image Influence Repurchase Intention for PB Rice. Journal of Distribution Science, 12(12), 83-90.

Kim, G. Y., \& Yeo, H. G. (2009). The Effect of Convention Center Image on Satisfaction and Affection. Journal of Hotel Management, 18(1), 311-323.
Kim, T. H., \& Lee, J. Y. (2013). The Effect of the Festival Image Match on Urban Brand Flow and Regional Loyalty. International Journal of Tourism and Hospitality Research, 27(4), 119-136.

Lee, I. S. (2012). The Influence of Perception on Attitudes and Loves of Korean Native Food Brand. International Journal of Tourism and Hospitality Research, 26(4), 402415.

Lee, J. W. (2017). Critical Factors Affecting Consumer Acceptance of Online Health Communication: An Application of Service Quality Models. The Journal of Asian Finance, Economics and Business, 4 (3), 85-94.

Oh, S. H., Shim, G. Y., \& Shin, B. D. (2002). Effect of Virtual Store Image on Satisfaction, Trust and Affinity in ECommerce. Journal of Global Scholars of Marketing Science, 10(1), 165-185.

Park, E. Y. (2016). The Effect of Color on Perceived Price Attractiveness: Interaction of Regulatory Focus and Involvement. Journal of Distribution Science, 14(10), 117126.

Sanjeev, P., Pranay, V., Chandan, P., \& Sai, V. (2015). Factors Defining Store Atmosphere in Convenience Stores: An Analytical Study of Delhi Malls in India. The Journal of Asian Finance, Economics and Business, 2(3), 5-15.

Seo, S. Y., Kim, S. D., \& Lee, M. S. (2018). The Effects of Knowledge Assets on the Performances of Startup Firms: Moderating Effects of Promotion Focus. The Journal of Asian Finance, Economics and Business, 5(4), 187-199. 